\title{
Mothers' Stress in Families of Children with Mental Handicap
}

\author{
Lama M. Al-Qaisy \\ Department of Psychology, Faculty of Education, Tafila Technical University \\ P.O. Box (179), Tafila 66110, Jordan \\ E-mail: lamaqaisy@yahoo.com
}

Received: August 8, 2011

Accepted: September 11, $2011 \quad$ Published: February 1, 2012

doi:10.5539/ass.v8n2p80

URL: http://dx.doi.org/10.5539/ass.v8n2p80

\begin{abstract}
This study aims to determine the intensity of stress experienced by the mothers of children with mental handicap, and identifies the stress of mothers with some variables as: age and sex of children and age of mothers, among a sample of 235 Mothers of children with mental handicap who were selected in a randomized sample. The results indicate that mothers total stress score is at a severe level. Additionally, the results indicate that mothers' stress does not differ with sex and age of the mental handicapped children. It also indicates that there is no difference between mothers' stress with relation to the age of mothers.
\end{abstract}

Keywords: Mental, Handicap, Stress, Intensity, Mothers

\section{Introduction}

Stress is a universal phenomenon. It is different for everyone; people who view stress as a stimulus define stress as an outside force that puts demand on them. Others define stress as a physical response going on within them. For others it is a transaction, an exchange between a stimulus and our perception of it, and the response it causes. Some describe stress as a part of larger whole. It is a part of an individual's physical, social, and emotional (Blonna, 2000). Schafer (2000) defines stress as the arousal of mind and body in response to demands made upon them. A stressor is any event or stimulus that causes an individual to experience stress.

Stressors can be broadly classified as internal or external stressors, or developmental or situational stressors. Internal stressors originate within stressor a person and external stressors originate outside the individual. Stressors represent the gap between perceived demands and perceived resources for handling them. People who view demands through magnifying filters and people who underestimate their resources are likely to experience considerable stress (Hayden and Goldman, 1996). Parents having a child with disability suffer from an external Stressor. Parents may feel ambivalent and depressed after having their child diagnosed as mentally handicapped (Ziler and Hodapp, 1986). Initially there is increased frustration. Mentally handicapped is a worldwide problem and age old problem. It is one of the greatest causes of human suffering. But it has been recognized as very serious since the second half of the nineteenth century. A handicapped child born in to family and grown in to adulthood is one of the most stressful experiences for a family. Parental reactions to the realization that their child is exceptional usually include shock, depression, sadness, and anger. Individuals differ in their handling to these feelings and getting adjusted to these stressful situations (Floyd and Philippe, 1993).Accumulating evidence suggests that parents of children with mentally handicap often experience deleteriously high levels of stress (Hendriks, DeMoor, Oud and Savelberg,2000).

Then the parents begin to experience economic stress when there is no enough money for the needs of the family, and when one of the children in the family has mental handicap. There will be increased demands on the financial resources of the family to pay for medical care, and additional therapies. In regard to social interaction, they feel reluctant to attend social functions, and they experience difficulty to travel with this child. Parents feel that the child will be a nuisance to others and he cannot be disciplined. The family may find it difficult to entertain friends at home, or to visit others. Also emotional problems, a number of practical problems may make living with a handicapped child especially demanding. Parents are subjected to greater emotional stress in day- to -day management of the child. Extra time and energy for the care of the child, decreased leisure time activities and social interaction. A wide range of parental reactions have been documented on the discovery of the child's disability: isolated, despair, depression, shock, and marital disintegration (Blacher, 1984, Kazak, 1987). The 
overall family adaptation in families with a child with mental retardation is quiet varied. With some families coping well and others manifest more serious problems (Bristol and Schopler, 1984). No parents like retardation for their child. When faced with the reality most parents respond with acceptance and love (Backer et al, 1997). There are many differences between families in their vulnerability to stress. Similarly, there are many ways to cope with stress, but some are more adaptive than others. Mothers reported more stress from the personal consequences of parenting than the fathers. Mothers of children with mental handicap have been reported to show significantly higher stress levels and report more negative child characteristics than mothers of children without handicap, and also report higher frequencies of depression and struggles with challenging behaviors (Smith,Oliver,and Innocenti, 2001, Lessenberry and Rehfeldt, 2004). The mother feels depressed and hopeless when she realizes that nothing can remove the handicap from their child. She does not feel free to enjoy social events and therefore becomes more isolated (Bristol and Schopler, 1984). Some mothers even though they undergo more stress cope well and get adjusted to their situation, but some cannot cope better (Vernon and David, 2001).

Even though stress in the families caring for their children with mental retardation has received research attention, limited studies have been done to assess the stress level of mothers of children with mental retardation. Many studies describe problems or worries that parents of handicapped children face (Longo and Bond, 1984). In Jordan, especially in Tafila and Karak hardly few studies are done in this area. And measures should be taken to help mothers of handicapped children to reduce the stress.

The present study aims to determine the intensity of stress experienced by the mothers of children with mental retardation, and to determine the stress of mothers according to some variables.

\subsection{Hypotheses}

1-There is no significant difference in mothers' stress in total number of children in the family.

2- There is no significant difference in mothers' stress with relation to the age of the child.

3- There is no significant difference in mothers' stress with relation to the age of mothers.

4- There is no significant difference in mothers' stress with relation to the sex of the child.

\section{Method}

\subsection{Participants}

A total of 235 Mothers of children with mental handicap were selected in a randomized sample. (150) in AlAmal center for disability and the center for the blind and the deaf in Karak, (85) attending at Al- Amal center for disability in Tafila, participated in this study. Participants were between below35 and above 50 years of age. See table (1)

$<$ Insert Table 1 here $>$

\subsection{Instruments}

\subsubsection{Translation}

\subsubsection{Stress inventory scale}

The tool used in this study was translated from English to Arabic by a professional translator. And displayed on 10 arbitrators from the department of special education to make sure the validity, suitability, and clarity of the data. And to verify the reliability re- test has been used on an exploratory sample consisting of (40) mothers from outside the study and re-application with a time lag of two weeks. Pearson correlation coefficient has been calculated between the results of the two applications it was (.85). Cronbach's alpha for the current study sample was .90 .

Stress inventory for Mothers of children with mental handicap, (Houser, and Seligman, 1991). The questionnaire is to find out the intensity of stress experienced by the mother in various factors of stress due to the child's disability. Questionnaire contents of 6 dimensions and 53 items daily care stress, family emotional stress, social problems, financial problems, sexual problems of the child, and health problems of the child.

\section{Result}

To know intensity of mothers' stress, it has been computed. Means, standard deviations, and percentages are presented in table (2)

$<$ Insert Table 2 here $>$ 
Table (2) shows that means and stander deviations are $(72.44,70.21),(40.88,37.32)$.this indicated that mothers total stress score is at a Severe level.

$<$ Insert Table 3 here $>$

Table (3) shows that of the (232) children, (66) children belongs to 16-20 age group and 14 children are below 5 years. The means of stress, experienced by mothers of children below 5 years is 90.56 , and mothers of children above 21 years are 72.09 .

$<$ Insert Table 4 here $>$

Table (4) shows that $\mathrm{F}$ is not statistically significant. This means that mothers' stress does not differ with sex of the mentally handicapped children.

$<$ Insert Table 5 here $>$

Table (5) shows the means and standard deviations of the scores of mothers' stress with relation to the age of mothers.

$<$ Insert Table 6 here $>$

Table (6) shows that $\mathrm{F}$ value is not statistically significant. Hence it can be concluded that there are no differences between mothers' stress with relation to the age of mothers.

$<$ Insert Table 7 here $>$

Table (7) shows that the obtained t- value is not significant at 0.05 level. That means there is no difference in stress between mothers of the male and female children.

\section{Discussion}

The present study revealed that the mothers of children with mental handicap experience varying degrees of stress. The majority of mothers had severe stress and a very few had moderate stress. This finding is supported by Pedreson, Parsons, and Dewey (2004) who studied the stress levels experienced by the parents of mental retardation children. The results showed that the parents feel a greater degree of stress when child is suffering the mental retardation. Also, Hung and Yeh (2004) elicited that the severe level of stress in parent due to behavioral problems of the child. The result of this study shows that there are no differences between mothers' stress with respect to the age of mothers. This is consistent with the study of Benson et al (2008) who examined parent's predictor of latter adjustment in siblings of children with autism. Results indicated that there were no significant differences between age and education and the level of mothers' stress. And the results of this study indicate that the age of the mentally handicapped was insignificant with regard to the stress of mothers. Sex of the mentally handicapped child was found to have no significant role in stress of mothers. These findings are supported by Khamis (2006) who studies the psychological distress among parents of children with mental retardation in the United Arab Emirates. The results showed that the age and sex of the mentally handicapped was not statistically significant with regard to the stress of mothers. And the study conducted by Sequeira et al (1990) Beckman (1983) also support the present study. Results indicated that there were no significant differences in the perceived burden with reference to the sex of the child. But the finding of the study conducted by Fry et al (1989) is a contradiction to that of the present study. He found that parents experienced greater parenting stress with boys, and child sex was particularly important for fathers.

\section{Conclusion}

Mental handicap of the child causes a great amount of stress to the mother. The majority of mothers had severe stress and a very few had moderate stress. Presence of behavior problems in mentally handicapped children is a serious concern for the mothers, and the areas producing stress for the mothers are the social and emotional stress. Some mothers shamed to participate in social functions with their mentally handicapped child (Crnic et al, 1983). Hence, awareness design programs that will help in shaping and correcting the attitudes of the society will be aware of the problems of families of mentally handicapped children, and the involvement of the family in the training and care of the mentally handicapped child helps in the diminution of the family emotional and social stress. This study was conducted only on mothers of children with mental handicap. The study can be done on the whole family. And a similar Study can be conducted with a larger sample and other variables.

\section{References}

Backer, B., Blacher, j., Kopp, C. \& Kraemer, B. (1997). Parenting Children with Mental Retardation. International review of research in mental retardation, 20, 1-14. http://dx.doi.org/10.1016/S0074-7750(08)60174-3 
Beckman, P. J. (1983). Influence of Selected Child Characteristics on Stress in Families of Handicapped Infant. American journal of mental deficiency, 88 (2), 150-156.

Benson, P., Paul, R., Kristie, L. \& Karlof. (2008). Child Parents and Family Predictors of Latter Adjustment in Siblings of Children with Autism. Research in autism spectrum disorders, 2(4), 583-600. http://dx.doi.org/10.1016/j.rasd.2007.12.002

Blacher, J. (1984). Sequential Changes of Parental Adjustment to The Birth of A Child with Handicaps: Fact or Artifact? Mental retardation, 22, 55-68.

Blonna, R. (2000). Coping with Stress in a Chaining World. (2 ${ }^{\text {nd }}$ ed.). United States. McGraw-Hillcompanies.

Bristol, M.M. \& Schopler, E. (1984). A Developmental Perspective on Stress and Coping in Families of Autistic Children. In M.C.Wang, M.C.Reynolds, and H.J.Walberg, (ed.). (1989). Handbook of special educationresearch and practice, 3. Oxford: Pergamon Press.

Crnic, K., Friedrich, W. \& Greenberg, M. (1983). Adaptation of Families with Mentally Retarded Children: A Model of Stress, Coping, and Family Ecology. American journal of mental deficiency, 88, 345-351.

Floyd, F.J. \& Philippe, K.A. (1993). Parental Interactions with Children and Without Mental Retardation, Behavior Management, Coerciveness and Positive Exchange. American journal on mental retardation, 97 (6), 678-688.

Fry, K., Greenbery, M. \& Fewell, R. (1989). Stress and Coping among the Parents of Handicapped Children: A Multidimensional Approach. American journal of mental retardation, 94, 240-249.

Hayden, M. \& Goldman, J. (1996). Families of Adults with Mental Retardation: Stress Levels and Need for Services. National association of social worker, 41(6), 657-666.

Hendriks, C., DeMoor, H., Oud, L. \& Savelberg, W. (2000). Perceived Changes in Well-Being of Parents with A Child in A Therapeutic Toddler Class. Research in developmental disabilities, 21,455-468. http://dx.doi.org/10.1016/S0891-4222(00)00058-5

Houser, R. \& Seligman, M. (1991). A Comparison of Stress and Coping By Fathers of Adolescents with Mental Retardation and Fathers of Adolescents Without Mental Retardation. Research in developmental disabilities, 12 (3), 251-260. http://dx.doi.org/10.1016/0891-4222(91)90011-G

Hung, J. \& Yeh, H. (2004). Comparing Stress Levels of Parents of Children with Cancer and Parents of Children with Physical Disabilities. Psycho-Oncology, 13 (12), 898-903. http://dx.doi.org/10.1002/pon.868

Kazak, A. (1987). Families with Disabled Children: Stress and Social Network in Three Samples. Journal of abnormal psychology, 25,137-146.

Khamis, V. (2006). Psychological Distress among Parents of Children with Mental Retardation in the United Arab Emirates. Social, science and medicine, 46, 850-857.

Lessenberry, B. \& Rehfeldt, R. (2004). Evaluating Stress Levels of Parents of Children with Disabilities. Council for exceptional children, 70 (2), 231-244.

Longo, D.C. \& Bond, L. (1984). Families of the Handicapped Child: Research and Practice. Family relations, 33, 57-65. http://dx.doi.org/10.2307/584590

Pedreson, S., Parsons, H \& Dewey, D. (2004). Stress Levels Experiences by the Parents of Entirely Fed Children. Child, care, health, and development, 30(5), 507-513. http://dx.doi.org/10.1111/j.1365-2214.2004.00437.x

Schafer.W. (2000). Stress management for wellness. ( $3^{\text {rd }}$ ed.). New York: Holt, Reinhart \& Winston.

Sequeira, E.M., Rao, P.M, Subbakrishna, D.K. \& Prabhu, G.G. (1990). Perceived Burden and Coping Style of The Mothers of Mentally Handicapped Children. NIMHANS journal, 8(1), 63-67.

Smith, B., Oliver, I. \& Innocenti, S. (2001). Parenting Stress in Families of Children with Disabilities. American journal of orthopsychiatry, 71, 257-261. http://dx.doi.org/10.1037/0002-9432.71.2.257

Vernon, H.G. \& David, J. (2001). Coping and Illness Cognitions: Chronic Fatigue Syndrome. Psychological studies, 21(2), 161-178.

Zler, E. \& Hodapp, R.M. (1986). Unresponsiveness in Children with Severe Disabilities: Potential Effects on Parent-Child Interactions. The exceptional child, 34(1), 32-36. 
Table 1. Mothers of children with mental handicap participated in this study

\begin{tabular}{lcccc}
\hline $\begin{array}{l}\text { Center } \\
\text { Age }\end{array}$ & $\begin{array}{c}\text { disability Al- Amal } \\
\text { at Karak }\end{array}$ & $\begin{array}{l}\text { the blind and the deaf } \\
\text { at Karak }\end{array}$ & $\begin{array}{l}\text { disability } \\
\text { Al- Amal } \\
\text { at Tafila }\end{array}$ & Total \\
\hline Below 35 & 32 & 20 & 39 & 91 \\
$36-45$ & 43 & 35 & 37 & 115 \\
Above 46 & 10 & 10 & 9 & 29 \\
\hline Total & 85 & 65 & 85 & 235 \\
\hline
\end{tabular}

Table 2. Means, and standard deviations for the intensity of stress by mothers of children with mental handicap

\begin{tabular}{cccc}
\hline Intensity of stress & $\mathrm{N}$ & $\mathrm{M}$ & $\mathrm{SD}$ \\
\hline Mild & 30 & 60.31 & 23.44 \\
Moderate & 80 & 70.21 & 37.32 \\
Severe & 112 & 72.44 & 40.88 \\
Profound & 13 & 40.56 & 18.56 \\
\hline Total & 235 & 243.52 & 120.23 \\
\hline
\end{tabular}

Table 3. Means and standard deviations of the scores of mothers' stress with relation to the age of the child

\begin{tabular}{llll}
\hline Age of child & $\mathrm{N}$ & $\mathrm{M}$ & $\mathrm{S}$ D \\
\hline Below 5 years & 14 & 90.56 & 39.30 \\
$6-10$ & 50 & 72.22 & 37.27 \\
$11-15$ & 60 & 72.50 & 42.45 \\
$16-20$ & 66 & 72.09 & 43.37 \\
Above 21 & 45 & 68.00 & 39.60 \\
\hline total & 235 & 71.49 & 40.98 \\
\hline
\end{tabular}

Table 4. ANOVA of mothers stress scores with respect to child's sex

\begin{tabular}{|c|c|c|c|c|}
\hline $\begin{array}{ll}\text { Source } & \text { of } \\
\text { variation } & \end{array}$ & $\begin{array}{l}\text { Sum of } \\
\text { squares }\end{array}$ & $\mathrm{DF}$ & Mean square & $\mathrm{F}$ \\
\hline Between Groups & 7756.95 & 5 & 1972.67 & 1.22 \\
\hline Within Groups & 3412.16 & 230 & 1657.26 & \\
\hline Total & 36897.88 & 235 & & \\
\hline
\end{tabular}


Table 5. Means and standard deviations of the scores of mothers' stress with relation to the age of mothers

\begin{tabular}{llll}
\hline Age of mothers & $\mathrm{N}$ & $\mathrm{M}$ & $\mathrm{S} \mathrm{D}$ \\
\hline Below 35 & 91 & 80.43 & 38.30 \\
36-45 & 115 & 70.02 & 42.62 \\
Above 46 & 29 & 60.29 & 30.44 \\
\hline total & 235 & 210.74 & 111.36 \\
\hline
\end{tabular}

Table 6. ANOVA of mothers stress scores with relation to the age of mothers

\begin{tabular}{lllll}
\hline Source of variation & $\begin{array}{l}\text { Sum of } \\
\text { squares }\end{array}$ & DF & Mean square & F \\
\hline Between Groups & 5440.79 & 4 & 2972.33 & 1.77 \\
Within Groups & 3978.29 & 227 & 1677.66 & \\
\cline { 1 - 4 } Total & 9419.08 & 231 & \multicolumn{2}{l}{} \\
\hline
\end{tabular}

Table 7. Means and standard deviations of mothers' stress scores with relation to the sex of the child

\begin{tabular}{lllll}
\hline Sex & $\mathrm{N}$ & $\mathrm{M}$ & $\mathrm{S} \mathrm{D}$ & $\mathrm{t}$ \\
\hline Male & 141 & 77.56 & 49.30 & -1.67 \\
Female & 91 & 82.22 & 37.27 & \\
\hline
\end{tabular}

